\title{
Teaching English Language In Elementary Education In The Albanian Context, Korça Region; The Syllabuses And Their Conformity To The Common European Framework Levels Of Linguistic Skills for Assessment
}

\author{
MSc. Edlira Xega \\ PhD candidate, Faculty of Education and Philology \\ English Language Department, University of Korca, Albania
}

Doi:10.5901/jesr.2013.v3n7p59

\begin{abstract}
The overall aim of this study is designed to explore various possibilities how the Albanian syllabuses are in conformity to Common European reference levels of linguistic proficiency. This study relies on qualitative and quantitative data through surveys, questionnaires and data analysis, held with Albanian English teachers and learners in the Albanian context.It is outlined the scope of syllabus design and its relation to the broader field of curriculum development. The primary focus of the study is the reform of curricula in the country of Albania. It provides information about what actually goes on between teachers and learners in pedagogical and linguistic interactional terms and how the designed syllabuses can be adopted to their needs and to the learners' outcomes. This article reports on the use of a second language classroom observation instruments in the syllabuses of elementary education and in particular to the objectives of the language skills. It is an observation which has been developed for analyzing learners' common reference levels, based on the 4 skills. It provides data for learners' language competencies, as they provide objective, quantifiable data and are obtained insights on what is actually happening in English language classrooms in the Albanian context. This survey is held in different kinds of schools in the city and villages of Korça. The survey research investigates what should learners actually know and what is their actual situation, how these linguistic skills are applied during the English classes in Korça and whether the standards set by CEFR are met.
\end{abstract}

Keywords: Common European reference levels, syllabuses, Albanian learners, linguistic skills, Albanian context, elementary and secondary schools.

\section{Teaching English language in the Albanian educational context}

\subsection{Educational process}

In all subjects and in the foreign languages as well, the process of modernization of curricula and of the educational process in primary school started in 1993 and continued later on. Certain innovations were implemented in schools in 1997/98. These changes have been based upon a critical estimation of objectives, content and complexity of curricula concerning subjects, content correlation and functionality of optional subjects and extracurricular activities. The curriculum reform should consider the quality of learning rather than the quantity, allowing more time for student to experiment, research, reflect, and synthesize information. (World data on education $6^{\text {th }}$ edition, 2006/2007)

It is of a high importance in the teaching process of the foreign language that teachers generally try to adapt all the things that actually happen in the teaching process in schools, to the aspects of the learning environment; having to do with the classroom atmosphere, organization, encouragement and support, promoting participation, presenting content information, the proposal of materials and tasks, monitoring, the offering of the objective information, that may help the learning process (Scrivener, 2007; 387). The teacher suggests what to study and how to organize the program of learning and the shape of individual lessons, raise awareness. (Harmer, 2007; 119).

Education in Korca region is implemented in public and private schools (native and foreign ones). The number of schools is 148, of which 129 are in village; 124 primary and lower secondary schools 23 secondary schools.

\section{What is syllabus?}

As it is assigned by CEFR, the Albanian curricula tend to be in line with the overall objective of promoting plurilinguism and linguistic diversity. This means that the teaching and learning of any language should also be examined in 
conjunction with the provision for other languages in the education system and the paths which learners might choose to follow in the long term in their efforts to develop a variety of language skills (Common European Framework of references, 2001; 169).

Definition of syllabus

- I would like to draw attention to a distinction . . . between curriculum or syllabus, that is its content, structure, parts and organization, and, what in curriculum theory is often called curriculum processes, that is curriculum development, implementation, dissemination and evaluation. The former is concerned with the "what" of curriculum: what the curriculum is like or should be like; the latter is concerned with the "who" and "how" of establishing the curriculum. (Stern 1984: 10-11)

- The syllabus replaces the concept of 'method', and the syllabus is seen as an instrument by which the teacher, with the help of the syllabus designer, can achieve a degree of 'fit' between the needs and aims of the learner and the activities which will take place in the classroom. (Yalden 1984: 14)

- Any syllabus will express-however indirectly-certain assumptions about language, about the psychological process of learning, and about the pedagogic and social processes within a classroom. (Breen 1984: 49)

- According to Candlin syllabuses are localized and are based on accounts and records of what actually happens at classroom levels as teachers and learners apply a given curriculum to their own situation. These accounts can be used to make subsequent modifications to the curriculum, so that the developmental process is ongoing and cyclical. (Candlin 1984; 29)

- An important step in the development of a language program is identifying learning goals. Nunan clearly presented goals, which are defined as general activities in which the learners will engage in real-world target language use (Nunan, 1996):

- To contribute to the intellectual, personal, and vocational development of the individual.

- To develop and maintain a sense of confidence and self-worth.

- To acquire the competence to use English in real-life situations for the development and maintenance of interpersonal relationships and to take part in interpersonal encounters through sharing factual information.

- To develop communicative skills in order to acquire, record, and use information from a variety of aural and written sources.

- To develop mastery over the English language as a linguistic system and to have some knowledge of how it works at the levels of phonology, morphology, and syntax.

\section{The syllabus designed for elementary educational system in Albania, Korça region, according to linguistic skills.}

Education should offer to the learner the necessary resources that build the knowledge and also the opportunity to exploit its own potential, by finding there a motivation to subsequent overruns. To this extend, didactics aims to create situations that allow the learner to make learning meaningful in that way they achieve their objectives: knowing, understanding, applying, analyzing, criticizing and inventing. The role of teaching is to guide the learner to acquire that reliable information about the nature of things and invest this information in the broader dynamics of research and creation (Sabbath; 39, 1984)

Syllabuses and curricula are an essential part of education. They are established by the government and by the Institute of Curricula and Training, part of the Ministry of Education in Albania. They come in the form of a set of educational principles, guidelines for teachers to follow and implement and adapt in their practice. They are designed to help teachers build their syllabus. They incorporate the latest research in teaching foreign languages and proposals of the Common European Framework of reference.

All the syllabuses are built and based on the age groups' interests and characteristics, and it largely contributes in the independent, intellectual and socio-cultural development of the learners. They aim the linguistic, intellectual and cultural development of the learners, by developing critical thinking learners; independence, by eliciting different forms of individual and group work.

On the other side all the goals, ideas and topics presented in syllabuses, interact with and are more accommodated to each teacher's personality, experience and preconceptions, and result in a teaching style or a plan of action that the teacher seeks to implement in the classroom. (Richards \& Nunan (ed.), 2002; 270) 


\section{The syllabuses designing principles}

The syllabus is a specification of a teaching program or pedagogic agenda, which defines a particular subject for a particular group of learners. It is a formulation of pedagogic goals; it is an instrument of educational policy as well. The goals are formulated not only in reference to pedagogic effectiveness but also in accordance with ideological positions concerning the nature of education in general, what Clark refers to as "educational value systems" (Widdowson, 2008; 127)

Syllabuses inspire the teacher to introduce methodological innovations in the planning and execution of activities in the classroom, which are consistent in some way with the conception of content. The main purpose of syllabus, is to alter the perspectives of teachers , and provide them with a different set of guidelines. (Widdowson, $2008 ; 129$ ).

The syllabuses, designed for the Albanian educational system, as the other syllabuses, are designed on a common national basis. This basis is filled in every teaching system, and in every school is based on and according to the social, cultural and economic characteristics of every region. The parameters of the national curricula are introduced in the intercommunity of didactics principles and the orientations that that teachers should follow for applying in their practice and adapting with the syllabus and in conformity with the selected textbooks.

These international curricular parameters integrate the research reality in the foreign languages didactics and the proposals of Common European framework for languages.

\section{The structure of the syllabus. - Elementary education}

Based on the law, the syllabus, of primary and secondary education, should be based on a common national basis. This basis is completed in each teaching system by a certain diversified party, according to the social, economical, cultural characteristics of each region. English curriculum for the elementary education is designed in accordance with the National Curriculum of Modern Languages for the Pre-University public Education, the Common European Framework of Reference for Languages in order to respond to an open society according to the needs that lie ahead teaching and to the acquisition of the English language in Albania (IKT; 2007-2008).

The Common European Framework of References for languages (CEFR) shows major categories of language use at each of the six levels. It is intended to help learners to profile their main language skills, and decide at which level they might look at a checklist of more detailed descriptors in order to self-assess their level of proficiency.

$3^{\text {rd }}$ Grades of the elementary education in Albanian context, start with level A1 and it is concentrated on understanding the language mainly by listening, responding in different ways with gestures, miming, written or orally, repetition and use of structures, basic words and phrases of English.

This level continues in the $4^{\text {th }}$ and $5^{\text {th }}$ Grades. The knowledge acquired in the two previous years are gradually enriched by motivating students of this age group. This program prepares the learner to pass to a new and more advanced level in terms of intercultural language .

In the $6^{\text {th }}$ and $7^{\text {th }}$ Grade, language acquisistion makes a step forward, by passing into level A2. The learner extends the knowledge about the culture of English-speaking countries, by further expanding his general knowledge.

The $8^{\text {th }}$ Grade continues continue with level A2+ by preparing to pass to level B1 and the learners are able to talk about the world around him, by expanding his knowledge about the culture of English-speaking countries, as well as his general knowledge.

Language acquisition in the $9^{\text {th }}$ grade continues with level B1. The syllabus presents linguistic knowledge, communication skills, and cultural values through which the learner reinforces and deepens the student's knowledge acquired in previous classes by increasing its expressive skills in English. It serves on the overall linguistic, socio-cultural and intellectual formation of learners (IKT, 2007-2008)

The syllabus for Grades 3-9 English language of the elementary education has as the object of study levels A1-B1 and the creation of sustainable communication skills and knowledge of students' socio cultural knowledge as initial user of the English language from the third to ninth grade elementary education, according to the Common European Framework of References.

English language syllabus in grades 3-9 enables learners of English in all four linguistic aspects (listening, speaking, reading and writing) and help students to acquire information and recognize the linguistic and cultural reality of English-speaking countries, understand the nature of a foreign language, and by relying on the knowledge of the native language to realize the relation of the foreign language with other subjects. (IKT Syllabus 2007- 2008)

English language in elementary school system (education) in Albania is held in classes 3 and 7 at 2 classes per 
week and in the $8 \mathrm{t}^{\mathrm{t}}$ and $9^{\text {th }}$ grade at 3 classes per week. Respectively:

\begin{tabular}{cccc}
\hline Class & Classes per week & Number of weeks & Total \\
\hline $3^{\text {rd }}$ & 2 & 35 & 70 \\
$\mathbf{4}^{\text {th }}$ & 2 & 35 & 70 \\
$\mathbf{5}^{\text {th }}$ & 2 & 35 & 70 \\
$\mathbf{6}^{\text {th }}$ & 2 & 35 & 70 \\
$7^{\text {th }}$ & 2 & 35 & 70 \\
8 $^{\text {th }}$ & 3 & 35 & 105 \\
$9^{\text {th }}$ & 3 & 35 & 105 \\
\hline
\end{tabular}

The syllabus of each grade is divided in: Communication and cultural education (32 classes), linguistic education (28) and free classes $(10)$; for classes $3^{\text {rd }}$ up to $7^{\text {th }}$. Communication and cultural education (57classes), linguistic education (38) and free classes (10) for 8th and 9th grade.

Total number of classes for elementary school is 560 .

Common European framework of references provides guidance on the number of guided teaching hours needed to fulfill the aims of each CEF level. These teaching hours are 60 minutes:

A1 level- Approximately 90 - 100 hours

A2 level- Approximately 180 - 200 hours

B1 level- Approximately 350 - 400 hours

These guided teaching hours are the hours during which the learner is in a formal learning context such as the classroom. In total they are approximately 400 teaching hours 60 minutes, or converted in 45 minutes teaching hours are 533 hours. If we see the concordance of the syllabuses of the Institute of Curricula and Training of the Ministry of Education in Albania, it results that in the Elementary education that includes levels A1- B1, the total number of 45 minutes teaching hours is 560 . If they are converted into 60 minutes teaching hours they are 420 .

More or less the total number of hours is nearly the same.

Below there are presented some data analysis and are drawn some statistics on the actual situation in Albania elementary schools, taken randomly, in Korca region; 6th and 8th grades.

\section{The study. Learners survey in elementary schools of Korca region; their linguistic achievements. How syllabuses meet the Albanian learners linguistic needs in English language. Observation and comparisons.}

Language skills are often divided into 2 types; Receptive skills - a term used for reading and listening, skills where meaning is extracted from the discourse. A productive skill is a term for speaking and writing skills where students actually have to produce language themselves. (Harmer; 2007, 265)

It is made a comparison of syllabus of elementary education in the different schools levels of Korca city and villages; whether there is a concordance to the Common European Reference levels.

\section{The aim of the survey}

This survey is focused in comparing the actual objectives designed by the Institute of Curricula and Training in Albania and Common European Framework of References (CEFR) that help learners actualize linguistic elements which are in accordance with the proper levels for each grade in elementary education and what learners have actually reached in different grades. The objectives of the syllabus pay special attention to accuracy and fluency of these linguistic elements in certain situations discourse, so that students can increase the level of self awareness in the use of linguistic knowledge.( IKT; 2010)

\section{Methodology}

The research presented here is a part of my doctorate thesis in which multiple samples of learners of elementary and secondary education were compiled over the year 2013. This study is based on some data collection, questionnaires, and survey realized with Albanian learners of English language in Korca city and its villages. All the data analysis is presented in different graphs. Learners were required to complete a questionnaire that examines their actual achievements in linguistic skills. They demonstrate their understanding and the English language acquisition at the level 
they belong to. This research derives its reliability from providing enough information to be able to make reasonable "comparisons" to situations in the Albanian contexts.

The classrooms survey data were analyzed both qualitatively and quantitatively, by drawing assumptions, principles, and even values about truth and Albanian teaching reality.

The qualitative analysis, which involved an examination of linguistic skills, revealed that classes taken into question belonged to different levels, different schools, and they use different English textbooks, but was based in the same syllabus. The "can do" statements that learners are supposed to assess themselves are selected based on the self assessment grid of the Common European Framework of References and on the objectives designed by the syllabuses of the Institute of Curricula and training, part of the Ministry of Education.

This analysis is clear and transparent, by showing the actual and real level of the Albanian learners in English language.

The quantitative analyses was conducted with questionnaires hand out to learners for analyzing what should learners actually know and what is their actual situation, how these linguistic skills are applied during the English classes in Korça and whether the standards set by CEFR are met. The principal findings of the study are evidences of the differences in knowledge and attitude of the learners, after they have acquired the sufficient knowledge, by doing a selfassessment.

Learners' levels differ depending on schools - urban and rural areas, and on methods being used.

The survey is held for a period of 3 months in different schools of Korça region.

In this study are taken these schools groups; $6^{\text {th }}$ and $8^{\text {th }}$ grades:

a. Elementary public schools- urban area

b. Elementary public school- rural area

c. Elementary private Albanian school- urban area

d. Elementary private foreign (Greek) school- urban area.

Based on this are reported the overall results of the survey:

The questionnaire consists in 15 questions divided by 4 skills; because the questions are numerous it is not possible to report all of them here. Instead, the results reported here are collected and grouped according to the skills. The results are presented in percentages, explained and presented in chart bars.

The questionnaire and the survey is held with a total number of 622 learners, 300 of them belong to the $6^{\text {th }}$ grades and 322 belong to $8^{\text {th }}$ Grades, age groups of $12-14$ Years old, with different backgrounds and belonging to different social levels.

\begin{tabular}{|c|c|c|}
\hline & $\begin{array}{l}\text { Nr. of learners } 6^{\text {th }} \text { Grades } \\
\text { Elem. public schools- urban area }\end{array}$ & $\begin{array}{l}\text { Nr. of learners } 8^{\text {th }} \text { Grades } \\
\text { Elem. public schools- urban area }\end{array}$ \\
\hline $\begin{array}{l}\text { Elem. public school using } \\
\text { foreign authors' textbook }\end{array}$ & 45 & 67 \\
\hline \multirow[t]{2}{*}{$\begin{array}{l}\text { Elem. public school using } \\
\text { Albanian authors' textbook }\end{array}$} & 60 & 50 \\
\hline & $\begin{array}{l}\text { Nr. of learners } 6^{\text {th }} \text { Grades } \\
\text { Elem. public schools - urban and rural }\end{array}$ & $\begin{array}{l}\text { Nr. of learners } 8^{\text {th }} \text { Grades } \\
\text { Elem. public schools - urban and rural area }\end{array}$ \\
\hline $\begin{array}{l}\text { Elem.public school rural area- } \\
\text { using foreign authors }\end{array}$ & 45 & 33 \\
\hline \multirow[t]{2}{*}{$\begin{array}{l}\text { Elem. public school- urban } \\
\text { area- using foreign authors }\end{array}$} & 45 & 67 \\
\hline & $\begin{array}{l}\text { Nr. of learners } 6^{\text {th }} \text { Grades Elem. private } \\
\text { schools - urban area }\end{array}$ & $\begin{array}{l}\text { Nr. of learners } 8^{\text {th }} \text { Grades Elementary } \\
\text { private schools - urban area }\end{array}$ \\
\hline $\begin{array}{l}\text { Elementary Albanian private } \\
\text { school - urban area }\end{array}$ & 52 & 60 \\
\hline \multirow{2}{*}{$\begin{array}{c}\text { Elementary Foreign private } \\
\text { school (Greek)- urban area } \\
\text { Total }\end{array}$} & 53 & 45 \\
\hline & 300 & 322 \\
\hline & & \\
\hline
\end{tabular}

\section{Discussion of the findings}


As it is presented above, there are taken into analysis the Elementary schools grouped in this way and the data will be compared based in these groupings. In each graph, in the vertical axis, are clearly presented the percentages of each level of the interviewed learners. The corresponding assessments are presented in colors and linguistic skills are presented in the horizontal axis.

The comparison is held in this way:

\section{$9.16^{\text {th }}$ Grades- Level A2.2}

\subsubsection{Elementary public schools- urban area}

- Elementary public school "Pandeli Cale" - using Albanian authors' textbook. -"Off we go 6"- Arberia Press.

- Elementary public school "Mesonjetorja I Shqipe "- using foreign authors' textbook., "Access 2 - Express publishing Press.
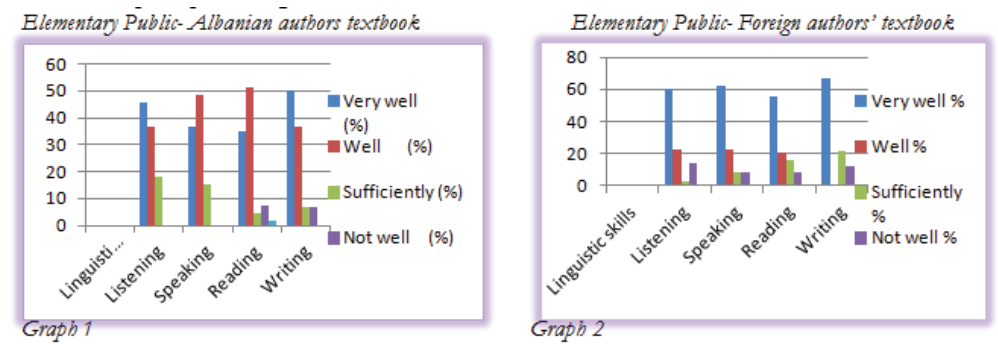

As it is clearly presented, from the total of 105 interviewed learners in these grades, the highest percentage in possessing very well the 4 linguistic skills is in Elementary Public-school, using foreign authors' textbook. The highest percentage of possessing well and sufficiently listening and reading linguistic skills is in Elementary Public-school, using Albanian authors' textbook, whereas Elementary Public-school, which use foreign authors' textbook has a higher percentage in possessing sufficiently speaking, reading and writing skills. It is also clearly seen that the higher percentage in possessing not well these skills is in Elementary Public-school, which use foreign authors' textbook. Maybe this latest fact show that using a foreign textbook at this level may be a little difficult to meet the learners' needs at A2.2 level.

The highest percentage of possessing the English language linguistic skills are in writing skill (very well) in Elementary Public-school, using Albanian authors' textbook and in writing skill (very well) in Elementary Public-school, using Foreign authors' textbook as well. The lowest percentage is in speaking skill in both cases.

\subsubsection{Elementary public schools -urban and rural area}

- Elementary public school -rural area, "Barç village", "Mehemet Fejzolli"- using foreign authors' textbook. "Access 2", Express publishing Press.

- Elementary public school- urban area, "Mesonjetorja I Shqipe"-using foreign authors' textbook. "Access 2", Express publishing Press.
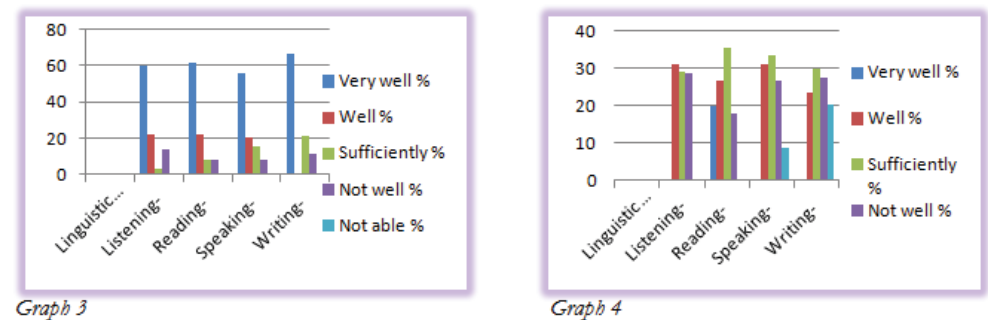
From 90 interviewed learners of these schools, belonging to $6^{\text {th }}$ grades, the highest percentage in possessing very well the 4 linguistic skills, has Elementary Public-urban area school which uses a foreign text, whereas in Elementary Publicrural area school which uses foreign authors textbook, the percentage of possessing very well the 4 linguistic skills is very low compared to the previous school. From the data provided in the graphs above this percentage is higher in possessing well, sufficiently and not well these skills, so learners in this school are not able enough to possess very well English language, especially by using the foreign authors' textbook. Another fact which shows that the learners of the rural area, who use a foreign textbook, are not able in writing and speaking skills, is shown by a considerable percentage of $20 \%$ in writing skill. textbook.

Apparently learners, who belong to the rural area, have difficulties for being adapted to the foreign authors

The highest percentage of possessing the English linguistic skills is very well in writing skill, and well in listening and reading skills in Elementary Public school -urban area using foreign texts. Regarding Elementary Public school -rural area using foreign authors' textbooks the highest percentage of possessing the English linguistic skills, is well in listening and speaking skill.

\subsubsection{Elementary private schools - urban area}

- Elementary Albanian private school - urban area- "Thimi Marko" using foreign authors' textbook. "Access 2 " textbook, Express publishing Press

- Elementary Foreign private school (Greek) - urban area-"Omiros" using foreign authors' textbook. - "Access 2" textbook- Express publishing Press.
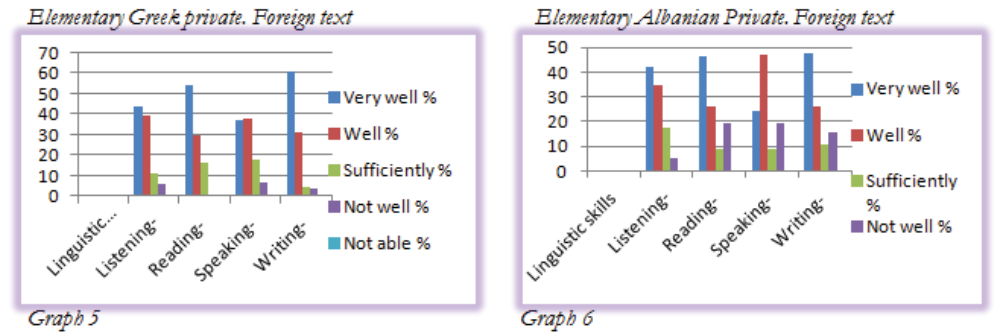

From the above data and results (graph 5 and 6 ) it is clearly seen that from 105 interviewed learners of these schools, the highest percentage of the Albanian learners who possess very well and well the 4 linguistic skills at this level (A2.2) is in Elementary Greek private school urban area, using foreign text. The lowest percentage in possessing the 4 skills is in Elementary Albanian Private school, urban area, using foreign text.

The skills in which the learners are more confident are writing and reading in Elementary Albanian Private school, urban area, using foreign text, very well in reading and writing and well in listening and speaking in Elementary Greek private school urban area, using foreign text.

\section{$9.28^{\text {th }}$ Grades- Level B1.1}

\subsubsection{Elementary public schools- urban area}

- Elementary public school "Pandeli Cale"- urban area, using Albanian authors' textbook. "Off we go 8" - Arberia Press

- Elementary public school "Mesonjetorja I Shqipe"- urban area using foreign authors' textbook. "Access 4"Express publishing Press. 


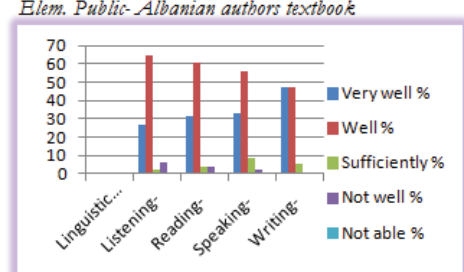

Graph 7

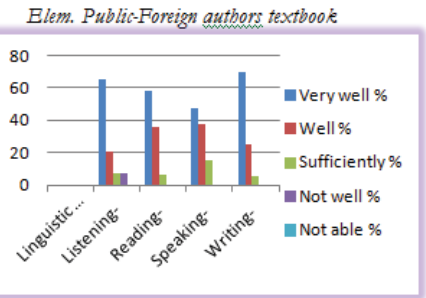

Graph 8

From the results drawn from the statistics provided above (graph 7 and 8) from 117 interviewed learners, the highest percentage in possessing very well the 4 linguistic skills is in Elementary Public-school, using foreign authors' textbook. The highest percentage of possessing well linguistic skills is in Elementary Public-school, using Albanian authors' textbook. The highest percentage in possessing sufficiently listening, reading and speaking linguistic skills has Elementary Public-school, using foreign authors' textbook, whereas in writing skill is Elementary Public-school, using Albanian authors' textbook. This school that uses Albanian authors' textbook has a higher percentage in possessing not well reading and speaking skills than the other school.

The highest percentage of possessing the English linguistic skills are very well in writing in Elementary Publicschool, using Albanian authors' textbook and well in reading. The lowest percentage in this school is in speaking and listening skill. This is shown in the fact that a small percentage of learners admit that are not well in listening and speaking.

Regarding Elementary Public-school, using foreign authors' textbook, the highest percentage of possessing the English skills, are very well in listening and writing and well in speaking and reading.

As it is obvious Albanian learners of this level feel better in writing skills, especially in Elementary Public-school, using Albanian authors' textbook.

\subsubsection{Elementary public schools -urban and rural area}

- Elementary public school "Mehmet Ferolli" Barc village, rural area- using foreign authors' textbook. "Access 2 ", Express publishing Press

- Elementary public school "Mesonjetorja I Shqipe", urban area- using foreign authors' textbook. "Access 2" Express publishing Press.
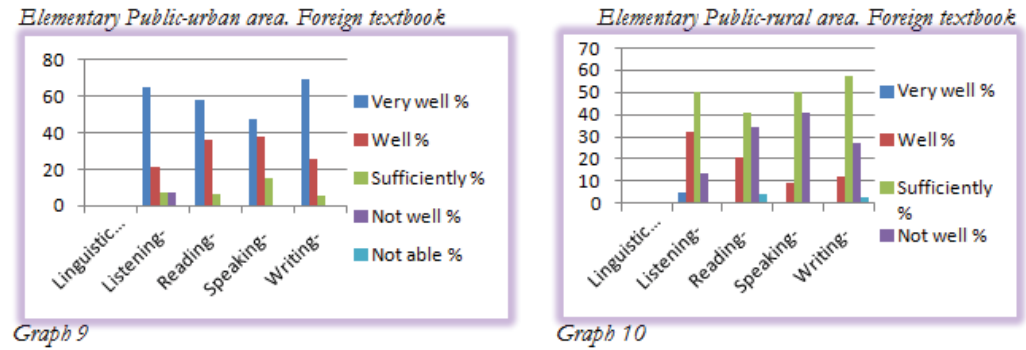

From 100 interviewed learners, belonging to urban and rural schools, the highest percentage of a very good acquirement of the 4 linguistic skills is for Elementary public school- urban area- using foreign authors' textbook, compared to only 4,6\% in Elementary public school -rural area- using foreign authors' textbook. The highest percentage in possessing well writing skills are the learners of Elementary public school- urban area- using foreign authors' textbook, and for reading well are the learners of Elementary public school -rural area- using foreign authors' textbook. Regarding writing skill the learners of Elementary public school -rural area- using foreign authors' textbook have a lot more difficulties compared to Elementary public school- urban area- using foreign authors' textbook. They take a high percentage in possessing sufficiently and not well speaking skills.

The highest percentage of possessing the English linguistic skills are very well in writing and in speaking in Elementary 
Public-school, using Albanian authors' textbook, and reading well for Elementary public school- urban area- using foreign authors' textbook.

It is observed that with the age growth there is a growth in the percentage of not possessing well or sufficiently the linguistic skills, and a decrease in very well and well level.

\subsubsection{Elementary private schools - urban area}

- Elementary Albanian private school "Thimi Marko", urban area, using foreign authors' textbook. "Access 4 ", Express publishing Press

- Elementary Foreign private school (Greek) "Omiros', urban area using foreign authors' textbook, "Access 4", Express publishing Press.
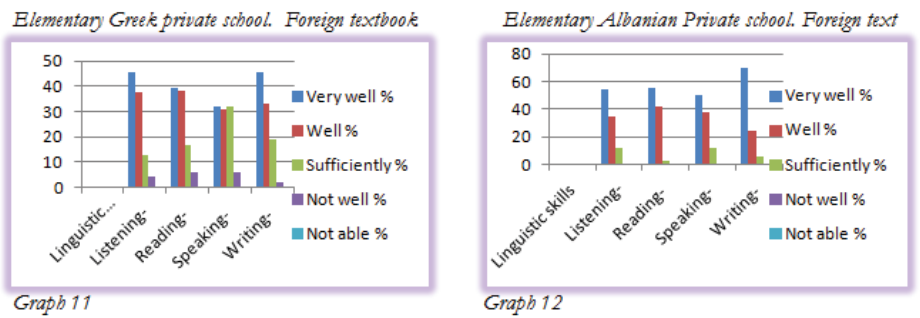

From the statistics taken from the $8^{\text {th }}$ grades in these two private schools (graph 11, 12), (105 interviewed learners) there are drawn out these results: The highest percentage in possessing very well the 4 linguistic skills, are in Elementary Albanian Private School, urban area using foreign text. In this school learners possess well reading and speaking skills as well.

The highest percentage in possessing sufficiently and not well the 4 linguistic skills is the Elementary Greek private school urban area using foreign text. A good indicator for Elementary Albanian Private School, urban area using foreign text, is the fact that there is not any percentage of learners who possess not well any of the 4 linguistic skills. The learners belonging to this school possess better Writing and reading skill; the above percentages show this.

The learners belonging to Elementary Greek private school urban area using foreign text possess very well listening and writing skills and well reading skill.

Generally talking Albanian learners have deficiencies in the Speaking skills and feel better at writing skills.

\section{Conclusions}

This study aimed at observing and comparing the actual objectives designed by the Institute of Curricula and Training in Albania and Common European Framework of References (CEFR) that help learners actualize linguistic elements which are in accordance with the proper levels for each grade in elementary education and what learners have actually reached in different grades.

It should be noted that all the displaying data and results tend to provide evidence on the actual situation of English language acquisition in Elementary Albanian learners, by displaying differences in different social levels, different textbooks used, and different schools. It refocuses the purpose of this study on, revealing a synopsis of what was found and leads into the results of the findings. Each school is different and the conditions are never the same from one class to the next.

The statistical analysis revealed that the percentages in the acquisition of the linguistic skills vary based on the school, textbooks, and areas; urban or rural. The principal findings of the study are evidences of the differences in knowledge and attitude of the learners, after they have acquired the sufficient knowledge, by doing a self- assessment.

In the $6^{\text {th }}$ and $8^{\text {th }}$ grades of elementary public school- urban area using foreign authors' textbook, in spite of the best language acquisition in the 4 linguistic skills, the users of this textbook, has a higher percentage in possessing sufficiently these skills, compared with elementary public schools- urban area using Albanian authors' textbook. This fact shows that in schools with a high level of the learners foreign authors' textbooks should be used whereas in schools with a low level of learners Albanian authors' textbooks should be used; the last ones are easier to be assimilated by a lower level of Albanian learners. The linguistic skills that are 
best possessed by users of Albanian textbooks is writing and reading skill, and have deficiency in communicative skills, whereas skills that are best possessed by users of foreign authors' textbooks are listening, writing and then speaking.

- $\quad$ From the percentages of Elementary public schools -urban and rural area; $6^{\text {th }}$ and $8^{\text {th }}$ grades, in both grades that use foreign authors' textbook, a considerable difference is observed between these 2 schools; The learners of the urban area have the best language acquisition in 4 linguistic skills. The skills that are best possessed are writing and listening. The results of the linguistic assessment in the rural area are too low compared with those of the urban area. These facts show that rural learners have difficulties in the acquisition of the foreign language by using foreign authors' textbook.

- $\quad$ From the findings of Elementary private schools -urban area; Albanian private school and Foreign (Greek) private school, using foreign authors' textbook, it results that: learners of Greek private school, using foreign textbook, belonging to the $6^{\text {th }}$ grade has best assimilated the 4 linguistic skills compared with Albanian private school of this grade, but the result reverses for the $8^{\text {th }}$ grade learners of Greek private school, who have more deficiencies compared with the $8^{\text {th }}$ grade learners of Albanian private school. The skill which is better possessed in both schools is writing skill.

However, being based on these results, generally talking, Albanian learners, have a deficiency in the speaking skill.

All the objectives of the syllabus pay special attention to accuracy and fluency of the linguistic elements in certain situations discourse, so that Albanian learners can increase the level of self awareness in the use of linguistic knowledge.

The results of these findings generally indicate the actual situation of the Albanian elementary learners of Korca city, in the use of linguistic skills and there is an attempt in the compilation of the foreign language syllabuses, to be adapted and to follow more appropriately the standards set by the Common European Framework of References.

\section{References}

Breen, M.P. (1984): "Process Syllabuses for the Language Classroom." Oxford Pergamon press

Candlin, C.N. (1984). Syllabus design as a critical process. In C.J. Brumfit (Ed.) General English syllabus.

Common European Framework of Reference for Languages (CEFR), 2001

Harmer J. ( 2007): "The practice of English language teaching" Pearson Longman.

Nunan D.,,Callan C.N. and H G Widdowson (ed.)( 1987) Syllabus design. Oxford Press.

Scrivener J. (2005) "Learning teaching" second edition. Macmillian education. Scotprint Britain.

Stern, H. H. 1984. "Introduction, review and discussion" in C. J. Brumfit (ed.) 1984. General English Syllabus Design. Oxford: Pergamon. Programet mesimore per arsimin e mesem te ulet (6-8) Instituti I Kurrikules dhe trajnimit (2007-2008)

Rachel Desrosiers Sabbath (1984) Comment enseigner les concepts (vers un systeme de modeles d'enseignement) Presses de l'universite de Quebec

Richards, J \& Nunan D. (ed.)(2002). Second Language teacher education. Cambridge University press.

Widdowson H.G. (2008) Aspects of language teaching Oxford Univesity press

World data on education $6^{\text {th }}$ edition 2006/2007)

Yalden, J. 1984. "Syllabus design in general education" in C. J. Brumfit (ed.) 1984. General English Syllabus Design. Oxford: Pergamon 